\title{
Strategy and Technology to Recycle Wafer-Silicon Solar Modules
}

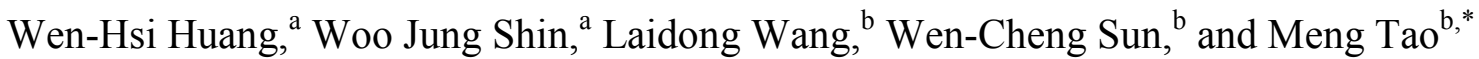

keywords: wafer-Si solar modules; end-of-life Si solar modules; end-of-life management; recycling.

\begin{abstract}
A major obstacle to sustainable solar technologies is end-of-life solar modules. In this paper, a recycling process is proposed for wafer-Si modules. It is a three-step process to break down Si modules and recover various materials. Over $95 \%$ of a module by weight can be recovered with this process. Two new technologies are demonstrated to enable the proposed recycling process. One is sequential electrowinning which allows multiple metals to be recovered one by one from $\mathrm{Si}$ modules, $\mathrm{Ag}, \mathrm{Pb}, \mathrm{Sn}$ and $\mathrm{Cu}$. The other is sheet resistance monitoring which maximizes the amount of solar-grade Si recovered from Si modules. The purity of the recovered metals is above $99 \%$ and the recovered Si meets the specifications for solar-grade $\mathrm{Si}$. The recovered $\mathrm{Si}$ and metals are new feedstocks to the solar industry and generate over $\$ 12 /$ module in revenue. This revenue enables a profitable recycling business for Si modules without any government support. The chemicals for recycling are carefully selected to minimize their environmental impact. A network for collecting end-of-life solar modules is proposed based on the current distribution network for solar modules to contain the collection cost. As a result, the proposed recycling process for wafer-Si modules is technically, environmentally and financially sustainable.
\end{abstract}

\section{INTRODUCTION}

A major obstacle on the horizon to sustainable solar technologies is end-of-life solar modules. As module deployment expands rapidly, so will module waste. The International Renewable Energy Agency estimates that waste modules will appear in large quantities by the early 2030's and by 2050, they will total 78 million tonnes (International Renewable Energy Agency, 2016). Among the different module technologies on the market, wafer-Si modules have always been the dominant technology with a $\sim 90 \%$ market share (Fraunhofer Institute, 2016). In 2015, the production of wafer-Si modules reached $59 \mathrm{GW}_{\mathrm{p}}$ (Fraunhofer Institute, 2016). This is equal to over 230 million modules, as wafer-Si modules are typically $\sim 250 \mathrm{~W}_{\mathrm{p}}$ each. With a lifetime of 25 years, these modules would be decommissioned in 2040.

Figure 1 illustrates the structures of the most common commercial wafer-Si solar cell and module. The Si wafer in the cell is 180-200 $\mu \mathrm{m}$ thick. The front emitter is $\sim 0.5 \mu \mathrm{m}$ thick and heavily n-type. The backsurface field (BSF) is $\sim 10 \mu \mathrm{m}$ thick and heavily p-type. The $\operatorname{SiN}_{\mathrm{x}}$ antireflection layer is $75 \mathrm{~nm}$ thick. The front electrode is $\mathrm{Ag}$ and the back electrode $\mathrm{Al}$. In a module, the cells are interconnected by soldering $\mathrm{Cu}$ wires onto them. The solder is made of $\mathrm{Sn}$ and $\mathrm{Pb}$. The interconnected cells, two sheets of ethylene vinyl acetate (EVA) and a backsheet of polyvinyl fluoride (PVF) are laminated to the front glass. An Al frame seals the edges of the module. A junction box (not shown in Fig. 1) is attached to the backside of the module for electrical connection. 
Recycling is rarely practiced for Si modules. As of today, only the European Union enforces solar module recycling. An organization, PV CYCLE, manages module recycling in Europe. The technology practiced by PV CYCLE for Si module recycling involves first stripping the Al frame and junction box from a module and then shredding the remaining module for glass (PV CYCLE). Si modules have a complex structure (Fig. 1(b)). As a rule of thumb, shredding or milling Si modules does not effectively separate the various materials in them (Dias et al., 2016, b; Granata et al., 2014). To finance PV CYCLE's operation, the European Union imposes a fee on module manufacturers. This fee is ultimately passed onto consumers.

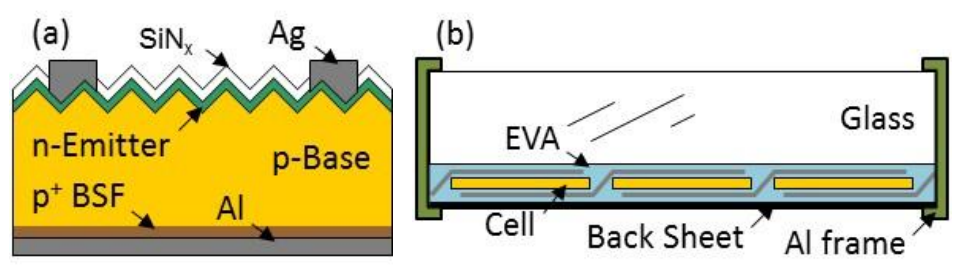

Figure 1. Schematics of the most common commercial wafer-Si solar cell (a) and module (b).

Three approaches have been reported to recycle the Si cells from the modules. Before 2005, the focus was on recovering the cells from the modules and then reusing the reclaimed cells in new modules. The key for this approach is a gentle method to separate the cells from the modules, so the cells remain intact. After the removal of the $\mathrm{Al}$ frame and junction box by mechanical measures, the backsheet can be peeled off (Bruton et al., 1994). There are three methods to detach the cells from the glass. The first method is to dissolve EVA in $\mathrm{HNO}_{3}$ (Bruton et al., 1994). This is a long process taking $24 \mathrm{hrs}$, and $\mathrm{HNO}_{3}$ damages cell components including the Ag and Al electrodes. The second method is to dissolve EVA in an organic solvent (Doi et al., 2001). A large number of organic solvents have been screened, and the process is really slow taking weeks. The process can be sped up with ultrasonic agitation (Kim and Lee, 2012), but the cost and energy input for the ultrasonic process are likely high. The third method is to thermally decompose EVA (Bohland and Anisimov, 1997; Zeng et al., 2004; Frisson et al., 2000; Dias et al., 2016, a). It can be carried out in a quartz-tube furnace, conveyor-belt furnace or fluidized-bed furnace in air or $\mathrm{N}_{2}$. The exothermic reaction of burning EVA serves as a heat source for the furnace (Frisson et al., 2000), reducing the energy input for the furnace. Since the reclaimed cells often suffer from damage (Frisson et al., 2000), the second approach is to reclaim the Si wafers from the modules. New cells are then fabricated on the reclaimed wafers. Reclaiming wafers requires the removal of the $\mathrm{Ag}$ and $\mathrm{Al}$ electrodes, $\mathrm{SiN}_{\mathrm{x}}$ layer, emitter and back-surface field (Frisson et al., 2000; Rover et al., 2005; Klugmann-Radziemska and Ostrowski, 2010, a; Klugmann-Radziemska et al., 2010, b; Park and Park, 2014). The chemicals for this purpose include $\mathrm{HF}$ for $\mathrm{SiN}_{\mathrm{x}}$ and $\mathrm{Al}, \mathrm{HNO}_{3}$ for $\mathrm{Ag}$, $\mathrm{NaOH}$ for $\mathrm{Si}$, a mixture of $\mathrm{HF}$ and $\mathrm{HNO}_{3}$ for $\mathrm{Si}$ and $\mathrm{SiN}_{\mathrm{x}}, \mathrm{KOH}$ for $\mathrm{Al}$, or $\mathrm{H}_{3} \mathrm{PO}_{4}$ for $\mathrm{Al}$.

Since 2005, the thickness of the wafers has been reduced to 180-200 $\mu \mathrm{m}$ (Fraunhofer Institute, 2016). The thin wafers prevent cell or wafer reclamation since the cells will all break during separation from the glass (Kang et al., 2012). Therefore, the most recent approach focuses on recovering the solar-grade Si from the cells (Klugmann-Radziemska et al., 2010, b; Huang and Tao, 2015; Muller et al., 2007). On the other hand, few papers have discussed metal recovery from Si modules (Huang et al., 2016). Two papers mentioned Ag recovery from $\mathrm{Si}$ cells by dissolving it in $\mathrm{HNO}_{3}$ and extracting it through electrowinning (KlugmannRadziemska and Ostrowski, 2010, a; Muller et al., 2007), but the Ag electrode in Si modules is actually covered under soldered $\mathrm{Cu}$. There has been no report on recovery of multiple metals from Si modules. 
In this paper we report our recent progress in wafer-Si module recycling. Our objective is to develop a recycling technology for $\mathrm{Si}$ modules that is technically, environmentally and financially sustainable. It involves a multi-step process to break down Si modules and recover various materials including all the toxic and valuable materials, solar-grade $\mathrm{Si}, \mathrm{Ag}, \mathrm{Pb}, \mathrm{Cu}$ and $\mathrm{Sn}$. The process recovers over $95 \%$ of the module by weight. The chemicals for recycling are carefully chosen so their wastes have a minimum environmental impact. More importantly, this recycling process generates a revenue stream of over $\$ 12 /$ module from the recovered solar-grade $\mathrm{Si}$ and $\mathrm{Ag}$, which is more than enough to cover the cost of recycling.

\section{INCENTIVES TO RECYCLE Si MODULES}

There are two valuable materials to recover from the Si cell in Fig. 1(a), solar-grade Si and Ag. The $\mathrm{SiN}_{\mathrm{x}}$ layer and Al back electrode are hard to recover. For the Si wafer, the front emitter and back-surface field are heavily doped. They are out of the specifications for solar-grade Si. Only the base can be recovered as solargrade $\mathrm{Si}$, which is boron doped to $\sim 1 \times 10^{16} \mathrm{~cm}^{-3}$. Once the cells are soldered for modules (Fig. 1(b)), there are three more metals to consider, $\mathrm{Pb}$ and $\mathrm{Sn}$ from the solder and $\mathrm{Cu}$ from the wires. While $\mathrm{Sn}$ and $\mathrm{Cu}$ may have enough values to recover, $\mathrm{Pb}$ is a toxic metal and should be removed from the recycling sludge (Fthenakis and Moskowitz, 2000, b; Tammaroa et al., 2016). Besides the valuable and toxic materials, the Al frame, junction box, front glass and polymer sheets (EVA and PVF) should be recycled as well. These components have little values as raw materials (Fthenakis, 2000, a), but their recovery is environmentally sound.

A typical 60 -cell $\mathrm{Si}$ module contains $\sim 0.65 \mathrm{~kg}$ of $\mathrm{Si}$. If $85 \%$ of the $\mathrm{Si}$ is recovered as solar-grade $\mathrm{Si}$, it is worth $\$ 8.20 /$ module at $\$ 15 / \mathrm{kg}$ for solar-grade $\mathrm{Si}$. The module also contains $\sim 6.5 \mathrm{~g}$ of $\mathrm{Ag}$. If $95 \% \mathrm{of}$ the $\mathrm{Ag}$ is recovered, it is another $\$ 4.30 /$ module at $\$ 20 / \mathrm{oz}$ for $\mathrm{Ag}$. As a result, the valuable materials in a typical $\mathrm{Si}$ module add to over $\$ 12$, which is more than enough to cover the cost of recycling for a profitable recycling business without any government support. Our estimation is much higher than the analysis by the International Renewable Energy Agency, which predicts \$15 billion in revenue from recycling 78 million tonnes of solar modules (International Renewable Energy Agency, 2016). Our estimation is $\sim \$ 45$ billion from 78 million tonnes of solar modules. This is because our process keeps high-value materials in their pure, high-value forms.

A major contributor to the cost of solar module recycling is the cost to collect and transport solar modules which are scattered around in small quantities (Fthenakis, 2000, a). To contain the collection cost, we propose to utilize the current distribution network of solar modules in the reverse order as a collection network (Fig. 2). Installers go to homes to perform repair and pick up waste modules. The waste modules are shipped to retailers, then to distributors and finally to recyclers who operate centralized recycling plants and generate revenues by selling the recovered solar-grade Si and Ag to the solar industry. To finance the network, each party in this collection network receives monetary compensation from the next party in the value chain. 


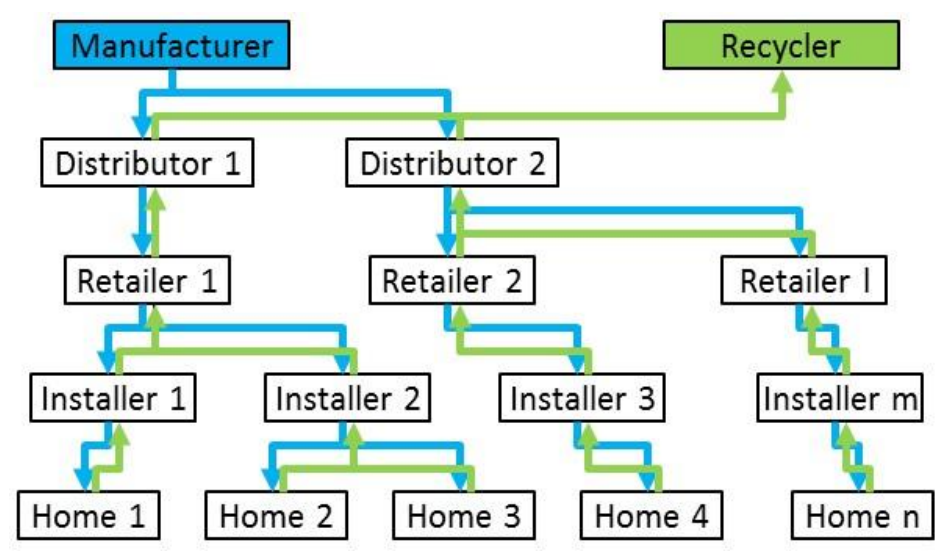

Figure 2. A collection network for solar module recycling based on the current distribution network.

There are more incentives to recycle Si modules. The availability of Ag is limited. The worldwide known reserve of $\mathrm{Ag}$ is $\sim 530,000$ tonnes (U.S. Geological Survey, 2015). At the current mining rate of 26,100 tonnes/year, the Ag reserve would be depleted in 20 years. Recovering Ag from waste Si modules is mandatory to sustain the current solar industry. There are also significant energy savings by recovering $\mathrm{Si}$ from waste Si modules. One of the most energy-intensive steps in the production of wafer-Si modules is the Siemens process, which reduces $\mathrm{SiHCl}_{3}$ to solar-grade Si (Tao, 2014; Tao et al., 2011). Recovering Si from $\mathrm{Si}$ modules bypasses the Siemens process. It is suggested that the energy input to produce a wafer-Si module is $400 \mathrm{kWh}$ with freshly-produced Si, but only $186 \mathrm{kWh}$ with recycled Si (Muller et al., 2005). This is a $\sim 55 \%$ energy saving.

\section{OUR PROCESS TO RECYCLE Si MODULES}

Figure 3 is our proposed process to break down wafer-Si modules and recover various materials. It involves three steps, module recycling, cell recycling and waste handling. In the first step, the junction box and Al frame are mechanically removed from a module. The polymer sheets (EVA and PVF) are then burned off to separate the cells from the glass in a furnace (Wang et al., 2012), which serve as a heat source for the furnace. This is different from the report on peeling off the PVF (Bruton et al., 1994), as PVF wastes can be either burned or buried. The glass is recycled and what is left is a string of interconnected cells. In cell recycling, interconnected cells are first immersed into a leaching solution to dissolve four metals, Ag, $\mathrm{Pb}, \mathrm{Cu}$ and $\mathrm{Sn}$. These metals are then recovered from the leaching solution one by one through electrowinning. The remaining cells are immersed into an etching solution to remove the $\mathrm{SiN}_{\mathrm{x}}$ layer and $\mathrm{Al}$ back electrode. Finally the cells are immersed into another etching solution to remove the emitter and backsurface field and to recover the base as solar-grade $\mathrm{Si}$. The remaining sludge goes to landfill. 


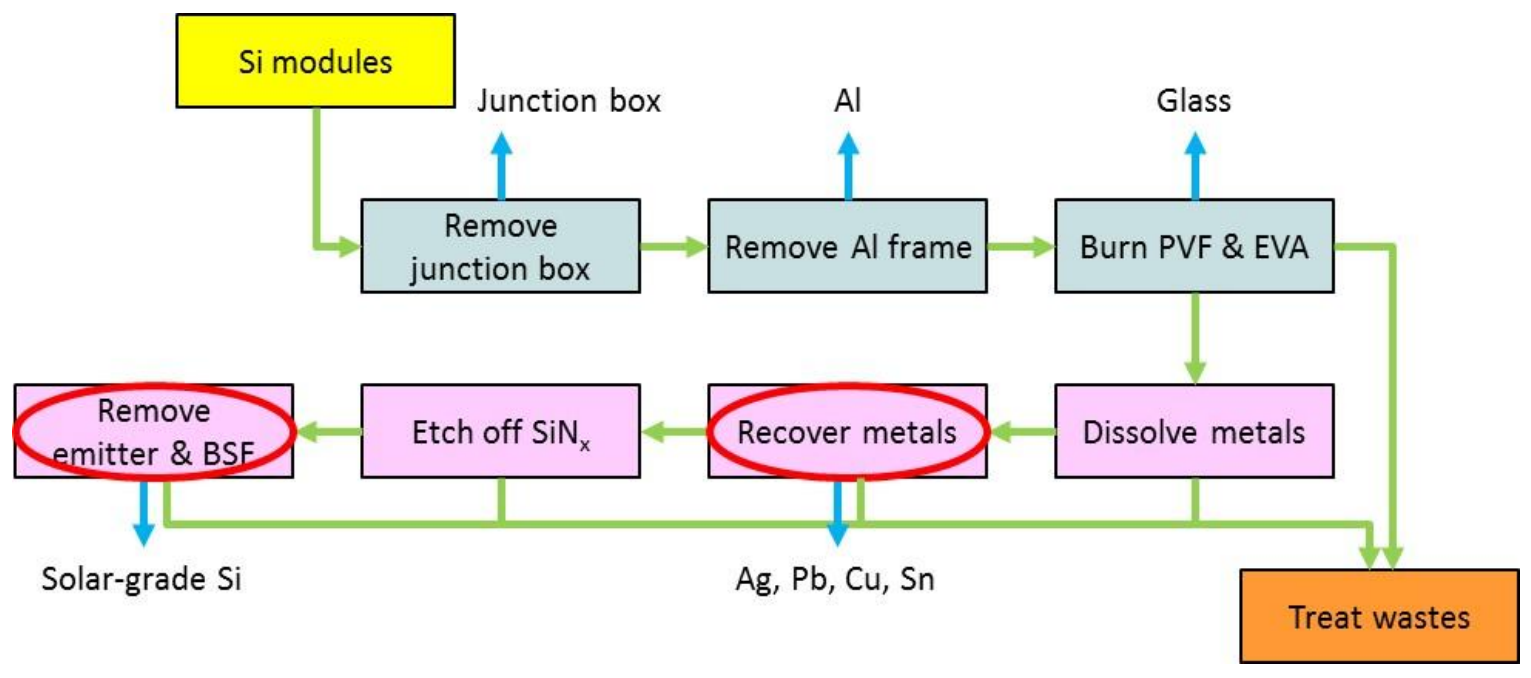

Figure 3. A proposed process to break down wafer-Si solar modules and recover various materials.

The chemicals selected for cell recycling are critical as they determine the waste chemicals we have to deal with. On the other hand, it is desirable to employ selective, self-limited chemistries for cell recycling (Fig. 4). We have purposely chosen $\mathrm{HNO}_{3}$ which dissolves only $\mathrm{Ag}, \mathrm{Pb}, \mathrm{Sn}$ and $\mathrm{Cu}$ from the cells (Fig. 4(a)), and $\mathrm{HF}$ which etches only $\mathrm{Al}$ and $\mathrm{SiN}_{\mathrm{x}}$ on the cells (Fig. 4(b)). With self-limited chemistry, process control becomes simpler as there is no over-etch to worry about. Finally $\mathrm{NaOH}$ is used to remove emitter and backsurface field. This is not a self-limited process, so a method to monitor the Si etch process is needed to maximize the amount of solar-grade Si recovered.

The last step is waste handling. Our recycling process generates three waste solutions, $\mathrm{NaOH}, \mathrm{HNO}_{3}$ and HF. $\mathrm{NaOH}$ and $\mathrm{HNO}_{3}$ can neutralize each other to form a solution of $\mathrm{NaNO}_{3}$, which is a fertilizer (U.S. Department of Agriculture, 2011). There is a well-established practice to treat HF wastes, i.e. $\mathrm{Ca}(\mathrm{OH})_{2}$ is added to $\mathrm{HF}$ to precipitate fluorine out as $\mathrm{CaF}_{2}$ (van den Broeck et al., 2003). There are also two gaseous exhausts from the recycling process. One is the exhaust from the polymer-burning furnace, which contains fluorine. The other is the exhaust from metal dissolution in $\mathrm{HNO}_{3}$, which contains $\mathrm{NO}$ and/or $\mathrm{NO}_{2}$. Scrubbers are required to trap fluorine in water as $\mathrm{HF}$ and to trap $\mathrm{NO}$ and $\mathrm{NO}_{2}$ in water as $\mathrm{HNO}_{3}$. It is possible to use the acids from the scrubbers in the recycling process. 

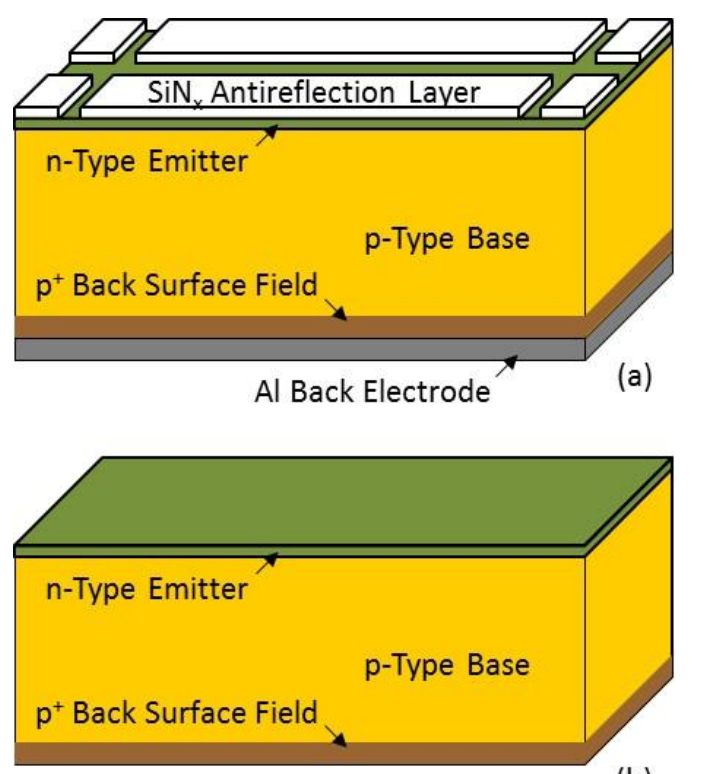

(b)

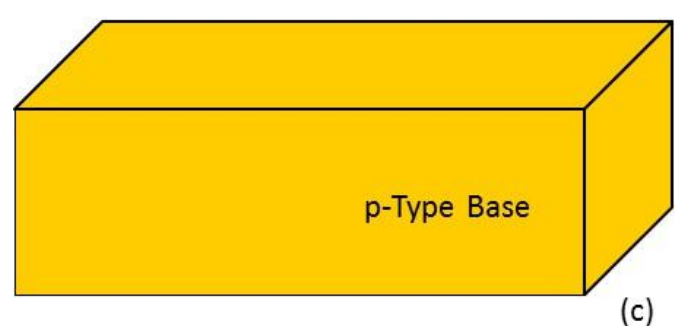

Figure 4. Self-limited chemistries for cell recycling: after $\mathrm{HNO}_{3}$ (a); after $\mathrm{HF}$ (b) and after $\mathrm{NaOH}$ (c).

It is estimated that over $95 \%$ of the module by weight can be recovered through our recycling process, as it can recover all the glass, Al frame, junction box, polymers (as heat source), 85-90\% of the Si and 90$95 \%$ of the metals. On top of $95 \%$ recovery, this process can generate over $\$ 12 /$ module in revenue by selling the recovered solar-grade $\mathrm{Si}$ and $\mathrm{Ag}$ to the solar industry.

\section{ENABLING TECHNOLOGY 1: SEQUENTIAL ELECTROWINNING}

For the proposed recycling process in Fig. 3, the technologies for module recycling and waste handling have been more or less developed or at least explored. However, the technology for cell recycling is not ready yet. In particular, the technology to recover multiple metals from Si modules and the technology to maximize the amount of solar-grade Si recovered need to be developed, which are circled in Fig. 3. Here we report our recent progress in multiple metal recovery (Huang et al., 2016). In the next section we will report our progress in solar-grade Si recovery (Huang and Tao, 2015).

After module recycling, interconnected cells are separated from the glass. These cells, intact or broken, are first immersed in $\mathrm{HNO}_{3}$ to dissolve four metals from the cells, $\mathrm{Ag}, \mathrm{Pb}, \mathrm{Sn}$ and $\mathrm{Cu}$. Although there has been no report on recovering multiple metals from Si modules, there are reports on recovering three of the four metals from printed circuit boards by leaching them in $\mathrm{HNO}_{3}$ (Yoo et al., 2012; Mecucci and Scott, 2002). Yoo et al. (Yoo et al., 2012) added $\mathrm{NaCl}$ to the leaching solution to precipitate Ag out as AgCl. This 
requires an extra step to convert $\mathrm{AgCl}$ to metallic Ag. Mecucci et al. (Mecucci and Scott, 2002) used electrowinning to recover $\mathrm{Cu}$ and $\mathrm{Pb}$ from the leaching solution. We believe that electrowinning is a more cost-effective approach as it can recover metals in their pure metallic forms. Furthermore, sequential electrowinning can recover multiple metals one by one from the leaching solution.

\subsection{Experimental}

To measure the metal recovery rate in electrowinning, a simulated leaching solution is utilized for the experiment. Metal contents in typical wafer-Si modules are listed in Table 1 (Bine Information Service, 2010). As Table 1 does not specify the Sn content in Si modules, it is assumed that the Sn content is the same as $\mathrm{Pb}$. $\mathrm{Al}$ does not dissolve in $\mathrm{HNO}_{3}$ and its reduction potential is too negative to allow recovery by electrowinning from an aqueous solution. As a result, $\mathrm{Al}$ is not included in this study. $0.0431 \mathrm{~g}$ of $\mathrm{Ag}, 0.72 \mathrm{~g}$ of $\mathrm{Sn}, 0.72 \mathrm{~g}$ of $\mathrm{Pb}$ and $4.31 \mathrm{~g}$ of $\mathrm{Cu}$ pellets are added to a 100-ml beaker. Their weight ratios follow Table 1 . An aqueous solution of $11.4 \% \mathrm{HNO}_{3}$ is poured into the beaker to dissolve the $\mathrm{Ag}, \mathrm{Pb}, \mathrm{Sn}$ and $\mathrm{Cu}$ pellets. The $\mathrm{pH}$ of the solution is between 0 and 1 . If the $\mathrm{pH}$ is less than 0 , it is found that $\mathrm{Ag}$ does not deposit on the Ti working electrode in electrowinning. The beaker is heated on a hotplate to $60^{\circ} \mathrm{C}$. After the metal pellets are completely dissolved, the solution is cooled down to $25^{\circ} \mathrm{C}$. The leaching solution after metal dissolution is shown in Fig. 5. The blue color is due to $\mathrm{Cu}^{2+}$ ions in the solution. The white precipitate at the bottom is $\mathrm{SnO}_{2}$, as observed in previous studies (Yoo et al., 2012; Mecucci and Scott, 2002). The precipitated $\mathrm{SnO}_{2}$ is recovered by filtration, but can be recovered by sedimentation as well.

\section{Table I}

Metal contents in wafer-Si solar modules by weight (Bine Information Service, 2010).

\begin{tabular}{|c|c|}
\hline Metal in wafer-Si module & Content (weight $\%$ ) \\
\hline $\mathrm{Al}$ & $10 \%$ \\
\hline $\mathrm{Si}$ & $\sim 3 \%$ \\
\hline $\mathrm{Pb}$ & $<0.1 \%$ \\
\hline $\mathrm{Cu}$ & $0.6 \%$ \\
\hline $\mathrm{Ag}$ & $<0.006 \%$ \\
\hline
\end{tabular}

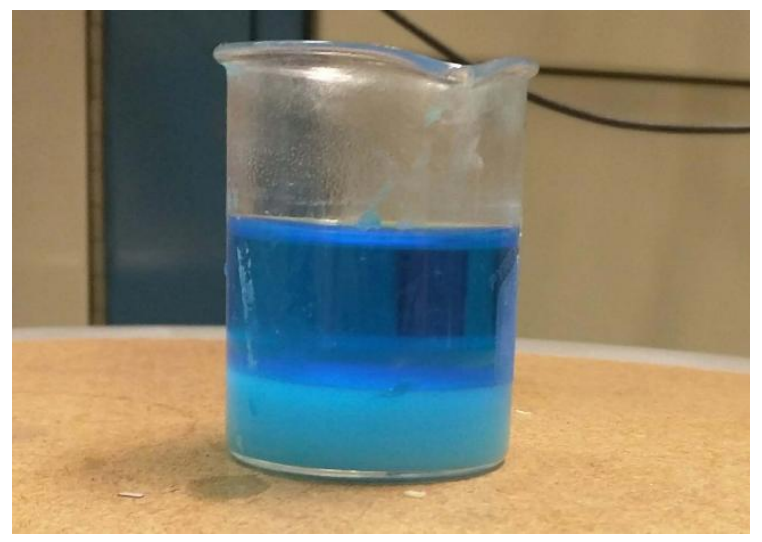

Figure 5. The $\mathrm{HNO}_{3}$ leaching solution after dissolution of four metals, $\mathrm{Ag}, \mathrm{Pb}, \mathrm{Sn}$ and $\mathrm{Cu}$. 
The leaching solution undergoes sequential electrowinning to recover the remaining metals, $\mathrm{Ag}, \mathrm{Cu}$ and $\mathrm{Pb}$. Fig. 6 illustrates the setup for sequential electrowinning, which involves three electrodes, a working electrode (W.E.), a counter electrode (C.E.) and a reference electrode (R.E.). Pt and Ti foils are used as the counter electrode and working electrode, respectively, since they are stable in concentrated $\mathrm{HNO}_{3}$. An $\mathrm{Ag} / \mathrm{AgCl}$ electrode is used as the reference electrode. A Gamry Reference 3000 potentiostat is used for electrowinning. Voltammetry is performed on the leaching solution to measure the reduction potential for each of the three remaining metals, $\mathrm{Ag}, \mathrm{Pb}$ and $\mathrm{Cu}$. The scan rate is $10 \mathrm{mV} / \mathrm{s}$. A progressively more negative voltage is then applied to the Ti working electrode to recover the metals one at a time. Each voltage is applied for 7,000 s. The deposit on the working electrode for each voltage is characterized by energydispersive $\mathrm{X}$-ray spectroscopy (EDX). For maximum recovery rates, the time for Ag recovery is increased to

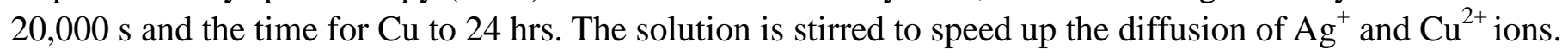

\section{$\underline{4.2 \text { Results and Discussions }}$}

Figure 7(a) is the voltammetry of the leaching solution. There is a large cathodic current at $\sim 0.1 \mathrm{~V}$ vs. the $\mathrm{Ag} / \mathrm{AgCl}$ reference electrode, indicating that something is reduced. If Fig. 7(a) is zoomed in between $0.45 \mathrm{~V}$ and $0 \mathrm{~V}$ as shown in Fig. 7(b), it shows two reduction reactions. The first reduction reaction begins at $\sim 0.43$ $\mathrm{V}$ and reaches a peak at $\sim 0.35 \mathrm{~V}$. The second reduction reaction occurs at $\sim 0.1 \mathrm{~V}$. Since Ag is the noblest metal and $\mathrm{Cu}$ is the second noblest in the solution, the first and second reduction reactions are attributed to $\mathrm{Ag}$ and $\mathrm{Cu}$ reduction, respectively. The window to separate $\mathrm{Ag}$ from $\mathrm{Cu}$ is between $0.43 \mathrm{~V}$ and $0.25 \mathrm{~V}$ from Fig. 7(b).

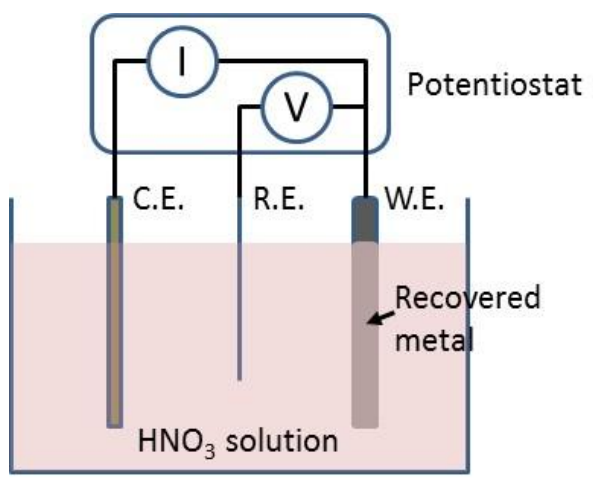

Figure 6. Schematic of the three-electrode electrolyzer for sequential electrowinning of multiple metals.

The Nernst equation defines the equilibrium reduction potential:

$$
E_{\text {red }}=E^{o}+\frac{R T}{n F} \ln [M]
$$

where $\mathrm{E}_{\mathrm{red}}$ is the reduction potential under nonstandard conditions, $\mathrm{E}^{\circ}$ the standard reduction potential, $\mathrm{R}$ the gas constant, $\mathrm{T}$ the absolute temperature, $\mathrm{n}$ the number of electron involved in the reaction, $\mathrm{F}$ the Faraday constant and $[\mathrm{M}]$ the concentration of the metal ion. The concentrations of $\mathrm{Ag}^{+}, \mathrm{Cu}^{2+}$ and $\mathrm{Pb}^{2+}$ in the simulated leaching solution are $5 \times 10^{-3} \mathrm{M}, 0.85 \mathrm{M}$ and $0.04 \mathrm{M}$, respectively. Their reduction potentials from 
the Nernst equation are $0.45 \mathrm{~V}, 0.128 \mathrm{~V}$ and $-0.38 \mathrm{~V}$ vs $\mathrm{Ag} / \mathrm{AgCl}$. The theoretical reduction potentials for $\mathrm{Ag}$ and $\mathrm{Cu}$ are very close to those from the voltammetry. Since the concentration of $\mathrm{Cu}^{2+}$ is much higher than $\mathrm{Pb}^{2+}$, its large reduction current shadows the reduction reaction of $\mathrm{Pb}^{2+}$ in the voltammetry.

Figure 8 shows EDX analysis of the deposits under different voltages on the Ti working electrode. Ti peaks show up due to the Ti electrode. Between $0.35 \mathrm{~V}$ and $0.25 \mathrm{~V}$, the deposits contain only Ag. However, when the voltage is less than $0.2 \mathrm{~V}, \mathrm{Cu}$ starts to show up in the EDX spectra. As a result, the window to recover $99 \%$ pure $\mathrm{Ag}$ is between $0.45 \mathrm{~V}$ and $0.25 \mathrm{~V}$ vs. $\mathrm{Ag} / \mathrm{AgCl}$ since the detection limit of EDX is typically below $1 \%$. The concentration of $\mathrm{Ag}$ in the solution decreases with time. The Nernst equation states that, when the concentration decreases, the reduction potential becomes more negative. Although the minimum voltage before $\mathrm{Cu}^{2+}$ reduction is $0.25 \mathrm{~V}, 0.3 \mathrm{~V}$ vs. $\mathrm{Ag} / \mathrm{AgCl}$ is chosen for $\mathrm{Ag}$ recovery.
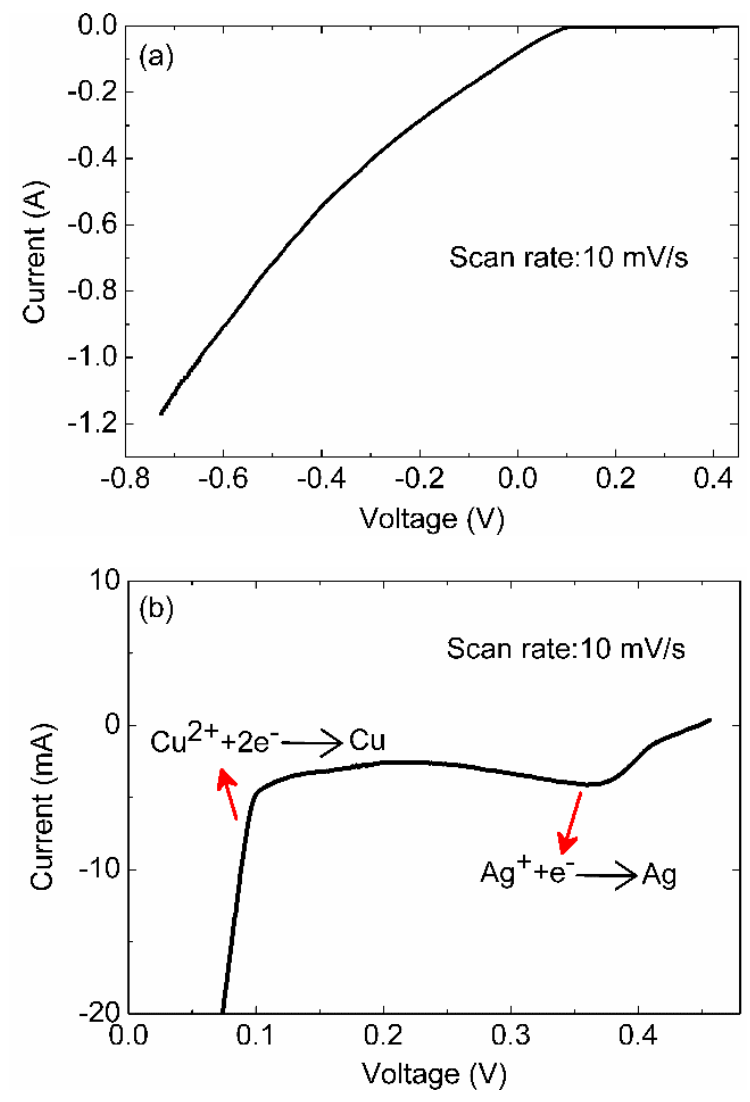

Figure 7. Voltammetry of the leaching solution (a) and zoom-in of (a) between $0.5 \mathrm{~V}$ and $0 \mathrm{~V}$ vs. $\mathrm{Ag} / \mathrm{AgCl}$ (b). 


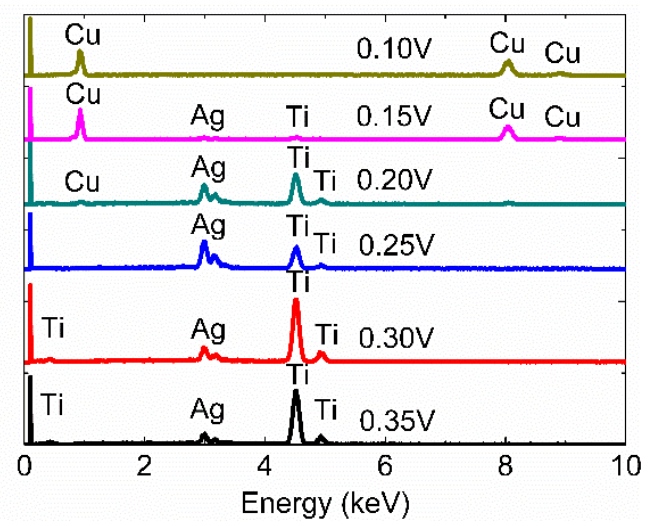

Figure 8. EDX spectra of the deposits on the Ti working electrode under different voltages vs. Ag/AgCl.

Figure 9 is the current vs. time plot for Ag recovery with the voltage on the Ti working electrode at $0.3 \mathrm{~V}$ vs. $\mathrm{Ag} / \mathrm{AgCl}$. The total electrowinning time is $20,000 \mathrm{~s}$. The reduction current decreases with time as the concentration of $\mathrm{Ag}^{+}$decreases over time. It does not reach zero, suggesting a kinetic limit to Ag recovery. Fig. 10 is EDX analysis of the deposit at $0.3 \mathrm{~V}$ vs. $\mathrm{Ag} / \mathrm{AgCl}$ for 20,000 s. It shows only $\mathrm{Ag}$ peaks from the recovered $\mathrm{Ag}$ and $\mathrm{Ti}$ peaks from the $\mathrm{Ti}$ electrode. The purity of the recovered $\mathrm{Ag}$ is at least $99 \%$. The recovery rate of $\mathrm{Ag}$ in this experiment is $74 \%$. This is obtained by measuring the weight gain of the $\mathrm{Ti}$ electrode and comparing it with the amount of $\mathrm{Ag}$ in the solution. By minimizing kinetic factors, the recovery rate of Ag can be significantly improved. The current efficiency for Ag recovery is $99.7 \%$.

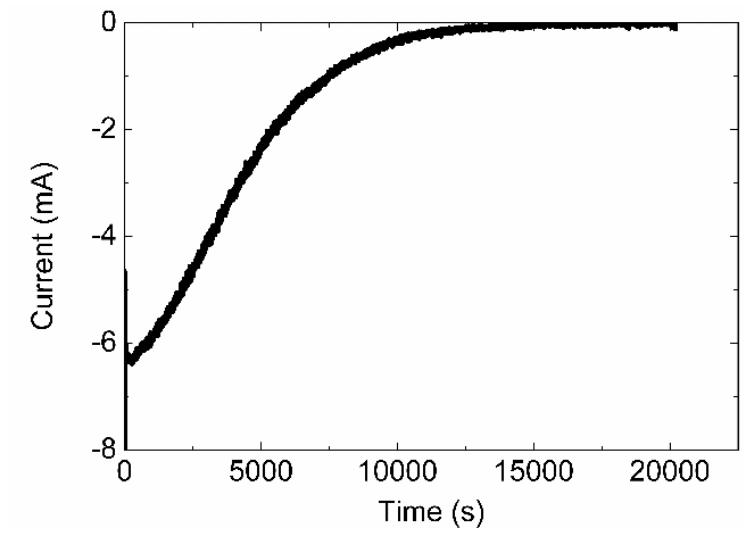

Figure 9. Current-time plot for Ag recovery at $0.3 \mathrm{~V}$ on the Ti working electrode vs. $\mathrm{Ag} / \mathrm{AgCl}$. 


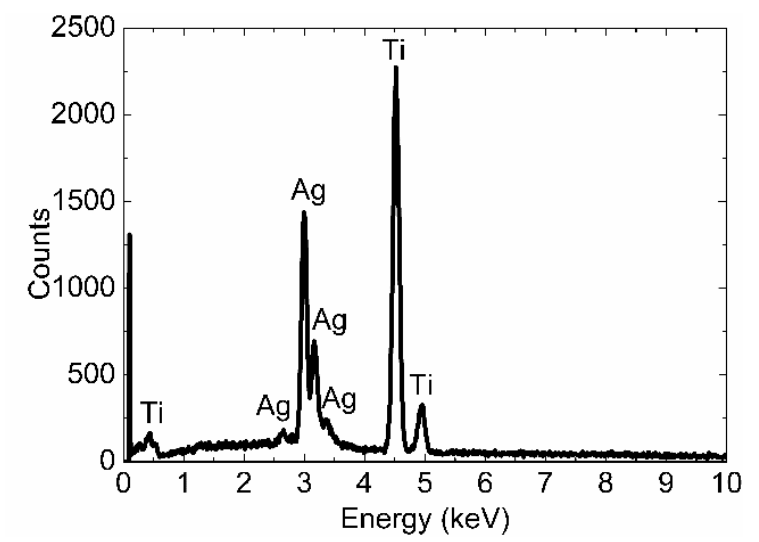

Figure 10. EDX spectrum of the deposit on the Ti working electrode at $0.3 \mathrm{~V} v \mathrm{vs} . \mathrm{Ag} / \mathrm{AgCl}$ for $20,000 \mathrm{~s}$.

Figure 11 compares the voltammetry of the leaching solution before and after Ag recovery. After $\mathrm{Ag}$ recovery, the $\mathrm{Ag}^{+}$reduction reaction at $\sim 0.35 \mathrm{~V}$ disappears and only the reduction reaction of $\mathrm{Cu}^{2+}$ is still present. This further proves that only Ag is removed from the solution during $\mathrm{Ag}$ recovery.

$\mathrm{Cu}$ recovery is performed after $\mathrm{Ag}$ recovery. $-0.3 \mathrm{~V}$ vs. $\mathrm{Ag} / \mathrm{AgCl}$ is applied to the Ti electrode. The reduction reaction of $\mathrm{Pb}^{2+}$ is shadowed by the reduction reaction of $\mathrm{Cu}^{2+}$ in Figs. 7 and 11 , and the theoretical reduction potential of $\mathrm{Pb}^{2+}$ from Eq. (1) is $-0.38 \mathrm{~V}$ vs. $\mathrm{Ag} / \mathrm{AgCl}$. Fig. 12 shows EDX analysis of the deposit on the Ti electrode at $-0.3 \mathrm{~V}$ for $24 \mathrm{hrs}$. There are $\mathrm{Cu}$ peaks but there is no $\mathrm{Pb}$ peak in EDX, indicating that $\mathrm{Cu}$ with $99 \%$ purity is recovered from the $\mathrm{Pb}^{2+}$-containing solution. The Ti peaks are not present as the $\mathrm{Cu}$ deposit is thick. The oxygen peak is due to oxidation of $\mathrm{Cu}$ on the Ti working electrode. The recovery rate of $\mathrm{Cu}$ is currently $83 \%$.

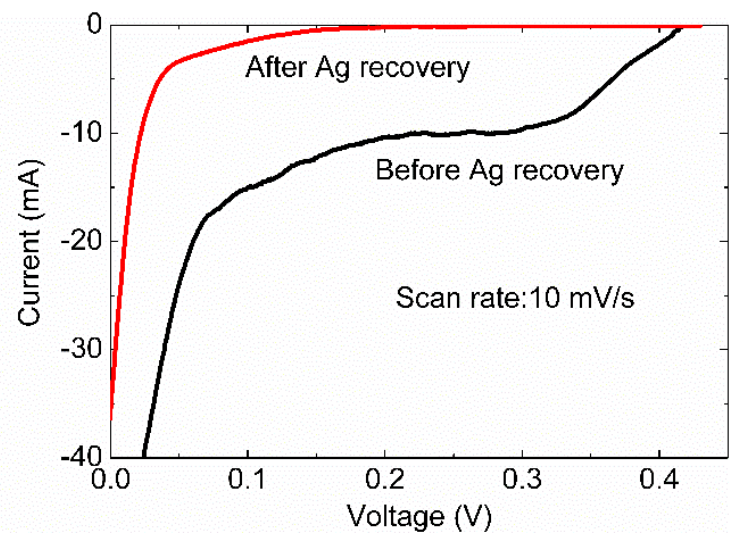

Figure 11. Comparison of voltammetry of the leaching solution before and after Ag recovery. 


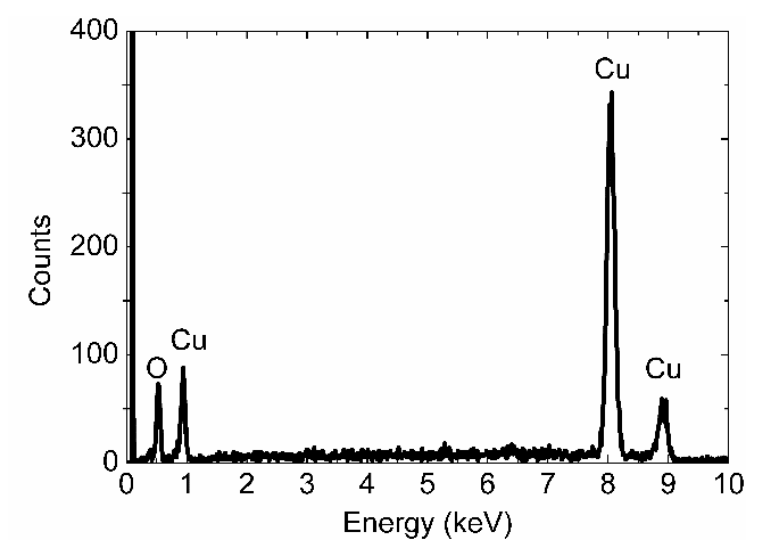

Figure 12. EDX spectrum of the deposit on the Ti working electrode at $-0.3 \mathrm{~V}$ vs. Ag/AgCl for $24 \mathrm{hrs}$.

It is found that $\mathrm{Pb}^{2+}$ ions deposit on the $\mathrm{Pt}$ counter electrode as $\mathrm{PbO}_{2}$ during $\mathrm{Cu}$ recovery, which is observed in a previous study (Mecucci and Scott, 2002). Fig. 13 is EDX analysis of the Pt electrode after $\mathrm{Cu}$ recovery. $\mathrm{Pb}$ peaks are present, indicating that when $\mathrm{Cu}$ is recovered on the $\mathrm{Ti}$ working electrode, $\mathrm{Pb}$ is also recovered on the Pt counter electrode from the solution. The oxygen peak is small, maybe due to the nonstoichiometric $\mathrm{PbO}_{\mathrm{x}}(\mathrm{x}<2)$ on the $\mathrm{Pt}$ counter electrode. The solution after $\mathrm{Cu}$ recovery for 48 hrs is investigated by inductively coupled plasma optical emission spectroscopy (ICP-OES). The results are listed in Table 2. Ag and $\mathrm{Cu}$ are largely removed. The $\mathrm{Sn}$ concentration is high because the filtration of $\mathrm{SnO}_{2} \mathrm{was}$ done only with a simple filter paper. With the $\mathrm{Pb}$ concentration at $92 \mathrm{ppm}$ and the volume of the solution at $60 \mathrm{ml}$, the amount of $\mathrm{Pb}$ in the solution is $\sim 5.5 \mathrm{mg}$. This is only $0.76 \%$ of the $\mathrm{Pb}$ in the starting solution, i.e. over $99 \%$ of the $\mathrm{Pb}^{2+}$ ions are removed from the solution during $\mathrm{Cu}$ recovery and the solution is almost free of toxic $\mathrm{Pb}$.

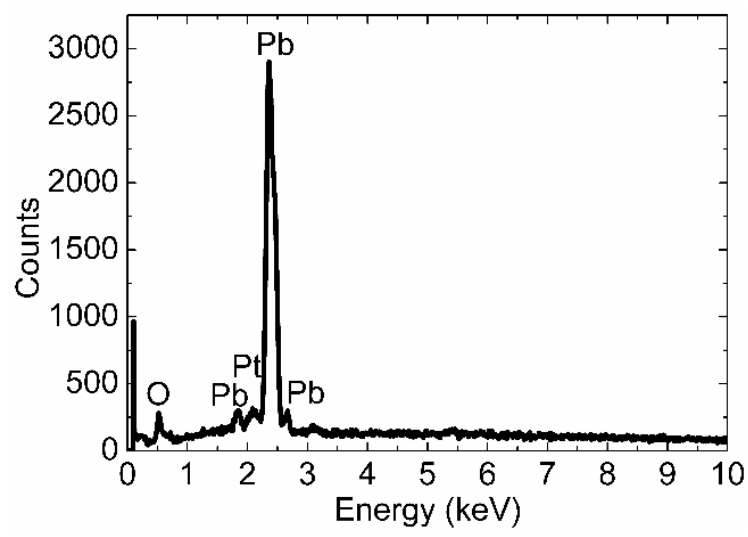

Figure 13. EDX spectrum of the deposit on the Pt counter electrode after Cu recovery for 24 hrs.

Table II

Metal contents in leaching solution after $\mathrm{Cu}$ recovery for 48 hours.

\begin{tabular}{|c|c|}
\hline Metal & Content $(\mathrm{ppm})$ \\
\hline $\mathrm{Ag}$ & 0.034 \\
\hline $\mathrm{Cu}$ & 3.38 \\
\hline $\mathrm{Pb}$ & 92.1 \\
\hline $\mathrm{Sn}$ & 426 \\
\hline
\end{tabular}




\section{ENABLING TECHNOLOGY 2: SHEET RESISTANCE MONITORING}

The cells after metal dissolution have the structure in Fig. 4(a). They are immersed into an aqueous solution of $10 \% \mathrm{HF}$ for $15 \mathrm{~min}$ to remove the $\mathrm{SiN}_{\mathrm{x}}$ layer and $\mathrm{Al}$ back electrode. The structure of the remaining cells is shown in Fig. 4(b), and the purpose of solar-grade Si recovery is to etch off the front emitter and back-surface field and to recover the base. We have carried out two studies for Si recovery (Huang and Tao, 2015). The first study is to optimize the conditions of $\mathrm{NaOH}$ etch for the highest etch rate of $\mathrm{Si}$. The second study is to maximize the amount of solar-grade Si recovered.

\subsection{Experimental}

To optimize the $\mathrm{NaOH}$ etch conditions, $\mathrm{Si}$ wafers are immersed into aqueous $\mathrm{NaOH}$ solutions of various concentrations from $1 \%$ to $50 \%$ at $25^{\circ} \mathrm{C}$, as the saturated $\mathrm{NaOH}$ concentration in water is $\sim 50 \%$ at $25^{\circ} \mathrm{C}$. The weight of the Si wafers is measured every $15 \mathrm{~min}$ and then converted to wafer thickness by the following equation:

$$
\text { Thickness }=\frac{\text { Weight }}{\text { Area } \times \text { Density }}
$$

It is assumed that the area of the $\mathrm{Si}$ wafer does not change after etch. Once the $\mathrm{NaOH}$ concentration for the highest etch rate is determined, the temperature of the $\mathrm{NaOH}$ solution is raised to $50^{\circ} \mathrm{C}$ to further increase the etch rate.

To remove the emitter and back-surface field, commercial monocrystalline-Si (mono-Si) solar cells are used. They go through $\mathrm{HNO}_{3}$ and $\mathrm{HF}$ to remove the front electrode, back electrode and $\mathrm{SiN}_{\mathrm{x}}$ layer. The remaining cells have the structure in Fig. 4(b). They are etched in an aqueous $\mathrm{NaOH}$ solution under the conditions identified above. Every 15 min, the cells are lifted from the $\mathrm{NaOH}$ solution and their sheet resistances are measured by a four-point probe on both the front and back sides. The reciprocal sheet resistances are then plotted against etch time to determine the precise moment when the heavily-doped emitter and back-surface field are just removed.

\section{$\underline{5.2 \text { Results and Discussion }}$}

Figure 14(a) shows the thickness loss of $\mathrm{Si}$ wafers as a function of etch time at $25^{\circ} \mathrm{C}$ under different $\mathrm{NaOH}$ concentrations from $10 \%$ to $50 \%$. Etch of Si starts after 15 min with stable slopes, i.e. constant etch rates, for all concentrations. The slow etch during the first $15 \mathrm{~min}$ suggests the presence of native oxide which hinders the etch rate. This assumption is verified in Fig. 14(b), which shows the thickness loss of two $\mathrm{Si}$ wafers in $10 \% \mathrm{NaOH}$, one with and the other without $10 \%$ HF pretreatment for 15 min. With HF pretreatment, the wafer shows a stable slope from the beginning, while the other wafer initially has little etch and then a stable slope after $15 \mathrm{~min}$. The etch rate of native oxide by $\mathrm{NaOH}$ is lower than that of $\mathrm{Si}$. With native oxide, there are two stages in the etch: (1) an oxide etch stage (first $15 \mathrm{~min}$ ) and (2) a Si etch stage (dashed circle). It is noted that the etch rate, i.e. the slope, for the HF-treated wafer is the same as the wafer without HF pretreatment after 15 min. This is clearly the Si etch stage. 
From Fig. 14(a), the etch rate in the $\mathrm{Si}$ etch stage increases when the $\mathrm{NaOH}$ concentration decreases. In order to increase the etch rate, the $\mathrm{NaOH}$ concentration is reduced below $10 \%$. Fig. 15 is the thickness loss of $\mathrm{Si}$ wafers as a function of etch time in $1 \%, 3 \%, 5 \%$ and $10 \% \mathrm{NaOH}$ aqueous solutions at $25^{\circ} \mathrm{C}$. None of these wafers goes through HF pretreatment, so they all have the oxide etch stage. The time for oxide etch is $15 \mathrm{~min}, 30 \mathrm{~min}, 45 \mathrm{~min}$ and $60 \mathrm{~min}$ for 10\%, 5\%, 3\% and 1\% NaOH, respectively. After oxide etch, all the wafers show stable slopes indicative of $\mathrm{Si}$ etch. From the slopes the etch rate of $\mathrm{Si}$ is determined, as shown in Fig. 16. The 3\% NaOH solution shows the highest $\mathrm{Si}$ etch rate, which is $0.082 \mu \mathrm{m} / \mathrm{min}$.
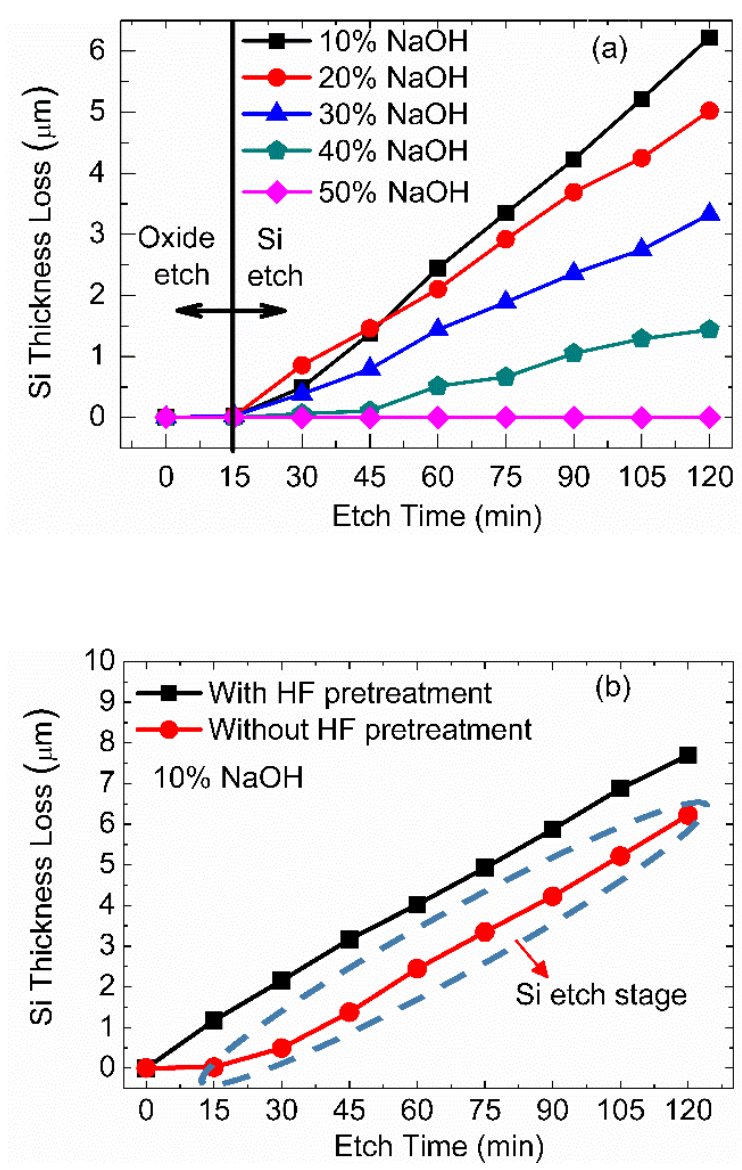

Figure 14. Thickness loss of $\mathrm{Si}$ in $\mathrm{NaOH}$ solutions of various concentrations at $25^{\circ} \mathrm{C}$ (a) and with or without HF pretreatment (b).

The back-surface field is $\sim 10 \mu \mathrm{m}$ thick. Even at $0.082 \mu \mathrm{m} / \mathrm{min}$, the etch rate is still too low for the backsurface field. In order to increase the etch rates of native oxide and $\mathrm{Si}$, the $3 \% \mathrm{NaOH}$ solution is heated to $50^{\circ} \mathrm{C}$. This temperature can be achieved by exposing the $\mathrm{NaOH}$ solution under sunlight. Fig. 17 shows the thickness loss of a $\mathrm{Si}$ wafer as a function of etch time in a $3 \% \mathrm{NaOH}$ aqueous solution at $50^{\circ} \mathrm{C}$. There is no oxide etch stage at $50^{\circ} \mathrm{C}$ and the $\mathrm{Si}$ etch rate is around $0.53 \mu \mathrm{m} / \mathrm{min}$. At this etch rate, the back-surface field can be removed in $\sim 20 \min .3 \% \mathrm{NaOH}$ at $50^{\circ} \mathrm{C}$ are the conditions used for actual cell etch.

Commercial mono-Si cells with the structure in Fig. 4(b) are immersed into a 3\% $\mathrm{NaOH}$ aqueous solution at $50^{\circ} \mathrm{C}$. Every $15 \mathrm{~min}$, the cells are lifted out of the $\mathrm{NaOH}$ solution and their sheet resistances are measured from both the front and back sides by a four-point probe. Fig. 18 plots the reciprocal sheet resistance of a cell as a function of etch time. Initially, the sheet resistances from the two sides are different because the 
sheet resistance from the front side is that of the $\mathrm{n}^{+}$emitter, and the sheet resistance from the backside is that of the $\mathrm{p}^{+}$back-surface field in parallel with the p-type base. After $15 \mathrm{~min}$, the two sheet resistances become identical. This happens when the $\mathrm{n}^{+}$emitter is completely removed. As a result, no matter which side the sheet resistance is measured from, it is always the sheet resistance of the $\mathrm{p}^{+}$back-surface field in parallel with the p-type base. After $30 \mathrm{~min}$, the plot changes its slope. This indicates the complete removal of the $\mathrm{p}^{+}$ back-surface field and only the lightly-doped p-type base is left. As soon as the slope changes, the etch should be stopped to recover the maximum possible amount of solar-grade Si from the cell.

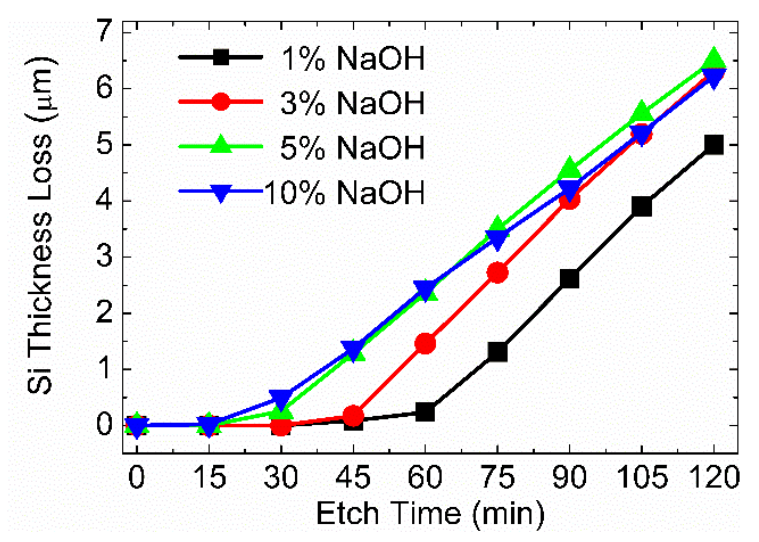

Figure 15 . Thickness loss of $\mathrm{Si}$ in $1 \%, 3 \%, 5 \%$ and $10 \% \mathrm{NaOH}$ aqueous solutions at $25^{\circ} \mathrm{C}$.

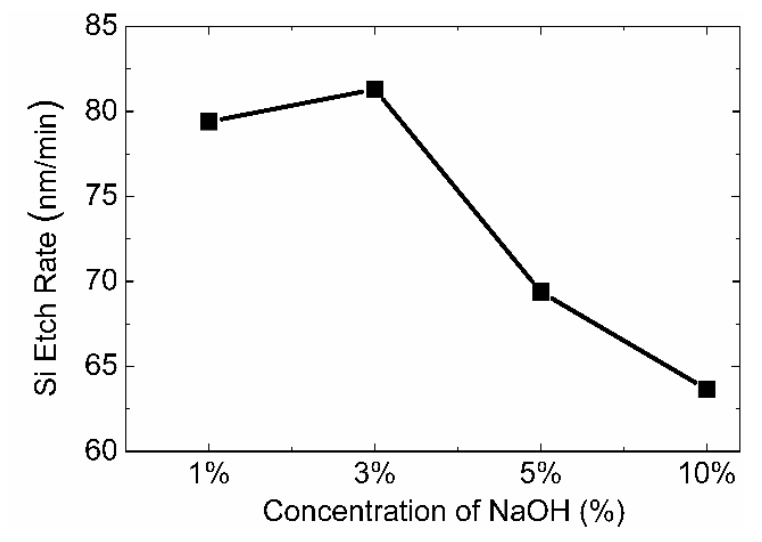

Figure 16. Si etch rate in $1 \%, 3 \%, 5 \%$ and $10 \% \mathrm{NaOH}$ aqueous solutions at $25^{\circ} \mathrm{C}$.

The backside of the cell contains a $\mathrm{p}$ layer and a $\mathrm{p}^{+}$layer in parallel. The reciprocal sheet resistance of the backside is:

$$
\frac{1}{R_{S}}=\frac{\rho_{p+} w_{p}+\rho_{p} w_{p+}}{\rho_{p+} \rho_{p}}
$$

where $R_{S}$ is the measured sheet resistance, $\rho_{p+}$ the resistivity of the $p^{+}$layer, $\rho_{p}$ the resistivity of the $p$ layer, $\mathrm{w}_{\mathrm{p}+}$ the thickness of the $\mathrm{p}^{+}$layer and $\mathrm{w}_{\mathrm{p}}$ the thickness of the p layer. Eq. (3) indicates that the measured sheet resistance of the backside is a function of the thicknesses of the $\mathrm{p}$ and $\mathrm{p}^{+}$layers. In Fig. 17, the thickness of the $\mathrm{Si}$ wafer has a linear relation with etch time in $3 \% \mathrm{NaOH}$ at $50^{\circ} \mathrm{C}$. As a result, the reciprocal sheet 
resistance of the backside is a linear function of etch time. This is verified by the straight line for the backside between 0 min and $30 \mathrm{~min}$ in Fig. 18.

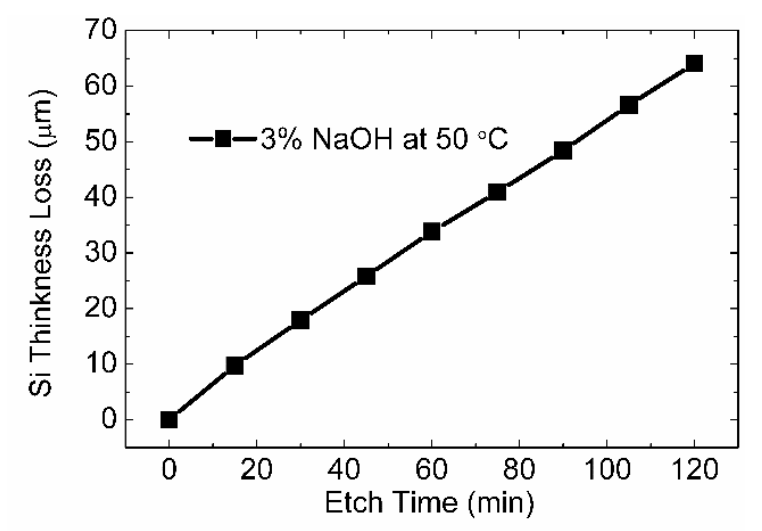

Figure 17. Thickness loss of $\mathrm{Si}$ in a $3 \% \mathrm{NaOH}$ aqueous solution at $50^{\circ} \mathrm{C}$.

When the $\mathrm{p}^{+}$layer is completely removed, the reciprocal sheet resistance of the backside becomes:

$$
\frac{1}{R_{S}}=\frac{w_{p}}{\rho_{p}}
$$

At this stage, the reciprocal sheet resistance is also linear with etch time because the thickness of the $\mathrm{p}$ layer has a linear relation with etch time. However the reciprocal sheet resistance shows a different slope. This is why the slope changes at $30 \mathrm{~min}$ in Fig. 18, and the point of slope change indicates that the $\mathrm{p}^{+}$back-surface field has just been completely removed. Since $w_{p}$ decreases with etch time at a constant rate, Eq. (4) can be rewritten as:

$$
\frac{1}{R_{S}}=-\frac{r \times t}{\rho_{p}}+C
$$

where $\mathrm{r}$ is the $\mathrm{Si}$ etch rate, $\mathrm{t}$ the etch time and $\mathrm{C}$ a constant related to the initial thickness of the $\mathrm{p}$-type base. With Eq. (5), one can find the resistivity of the p-type base, $\rho_{\mathrm{p}}$, by dividing the Si etch rate with the absolute value of the slope between $30 \mathrm{~min}$ and $120 \mathrm{~min}$ in Fig. 18. The etch rate of Si is $0.53 \mu \mathrm{m} / \mathrm{min}$ and the fitted slope is $-3.77 \times 10^{-5} \square / \Omega$-min. The $\rho_{p}$ calculated is thus $1.41 \Omega$-cm, which is in agreement with the specifications of the starting $\mathrm{Si}$ wafer. 


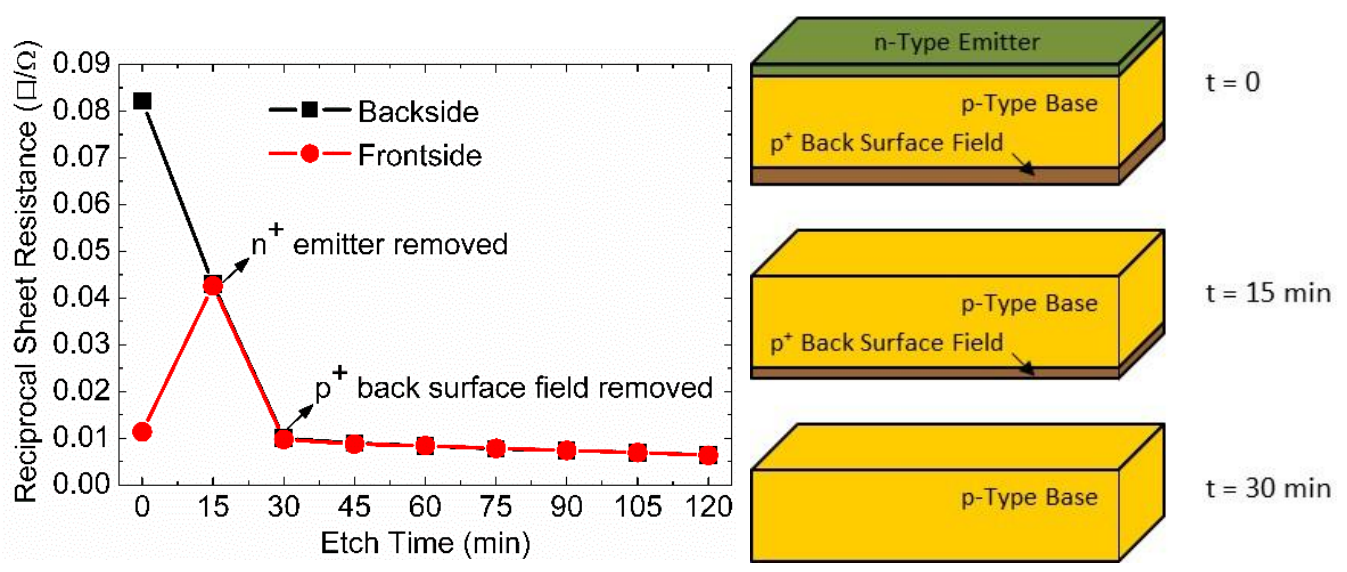

Figure 18. Reciprocal sheet resistance of a $\mathrm{Si}$ cell in a $3 \% \mathrm{NaOH}$ solution at $50^{\circ} \mathrm{C}$ as a function of etch time.

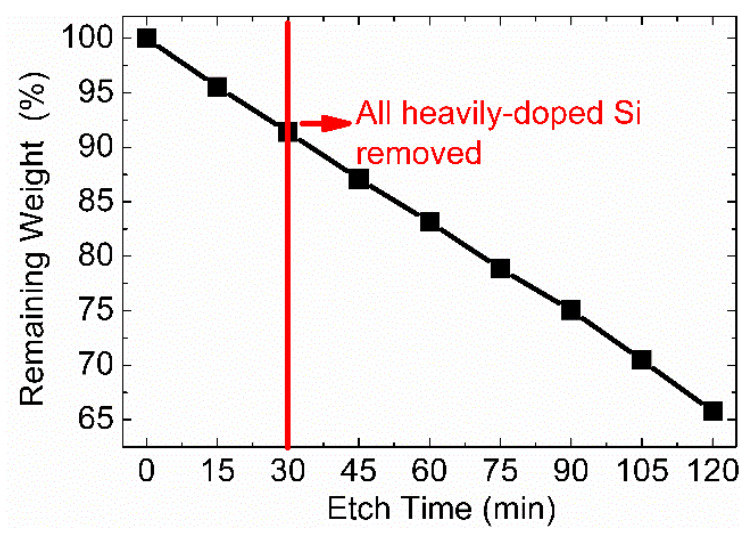

Figure 19. Remaining weight of a $\mathrm{Si}$ cell in a $3 \% \mathrm{NaOH}$ solution at $50^{\circ} \mathrm{C}$ as a function of etch time.

The remaining weight of a Si cell as a function of etch time has also been measured, as shown in Fig. 19. A 30-min etch removes all the heavily-doped layers. Fig. 19 reveals that after $30 \mathrm{~min}$, the remaining weight is $\sim 91 \%$ of the starting wafer, i.e. the amount of solar-grade Si recovered by sheet resistance monitoring is over $90 \%$.

\section{CONCLUSION}

A recycling process is proposed for wafer-Si solar modules that is technically, environmentally and financially sustainable. It is a three-step process, module recycling, cell recycling and waste handling, to break down Si modules and recover various materials. Over 95\% of a module by weight can be recovered by the proposed process including all the glass, Al frame, polymers (as heat source), junction box, 90\% of the $\mathrm{Si}$ as solar-grade $\mathrm{Si}$ and over $90 \%$ of the valuable and toxic metals. Two new technologies are demonstrated to enable the practice of the proposed recycling process. One is sequential electrowinning which allows multiple metals to be recovered one by one from $\mathrm{Si}$ modules, $\mathrm{Ag}, \mathrm{Pb}, \mathrm{Cu}$ and $\mathrm{Sn}$. The recovery rates of $\mathrm{Ag}$ and $\mathrm{Cu}$ are currently $74 \%$ and $83 \%$, respectively, but can be increased to $95 \%$. The purity of the recovered metals is above $99 \%$. The other technology is sheet resistance monitoring which maximizes the amount of solar-grade Si recovered from the modules. Over $90 \%$ of the $\mathrm{Si}$ in the original modules can be 
recovered, and the recovered $\mathrm{Si}$ meets the specifications for solar-grade $\mathrm{Si}$. The recovered metals and $\mathrm{Si}$ are new feedstocks to the solar industry and generate over $\$ 12 /$ module in revenue at today's prices for Ag and solar-grade $\mathrm{Si}$. This revenue eliminates a major obstacle to $\mathrm{Si}$ module recycling, enabling a profitable recycling business without any government support. The chemicals for recycling are carefully selected so their wastes can neutralize each other for a minimum environmental impact. A network for collecting endof-life solar modules is proposed based on the current distribution network for solar modules to contain the collection cost.

\section{ACKNOWLEDGEMENTS}

Financial support for this project is provided by the U.S. National Science Foundation under grant no. DMR-1306542. The authors thank Dr. G. Xing of Canadian Solar for providing mono-Si solar cells for this project.

\section{REFERENCE}

Bine Information Service, 2010. Recycling Photovoltaic Modules.

Bohland, J.R., Anisimov, I.I., 1997. Possibility of recycling of silicon PV modules. In: Proceedings of the 26th IEEE Photovoltaic Specialist Conference (PVSC), Anaheim, pp. 1173-1175.

Bruton, T.M., Scott, R.D.W., Nagle, J.P., 1994. Recycling of high value, high energy content components of silicon PV modules. In: Proceedings of the 12th European Photovoltaic Solar Energy Conference and Exhibition (EUPVSEC), Amsterdam, pp. 459-463.

Dias, P., Javimczik, S., Benevit, M., Veit, H., 2016, a. Recycling WEEE: Polymer characterization and pyrolysis study for waste of crystalline silicon photovoltaic modules. Waste Manage. in press.

Dias, P.R., Benevit, M.G., Veit, H.M., 2016, b. Photovoltaic solar panels of crystalline silicon: Characterization and separation. Waste Manage. Res. 34, 235-245.

Doi, T., Tsuda, I., Unagida, H., Murata, A., Sakuta, K., Kurokawa, K., 2001. Experimental study on PV module recycling with organic solvent method. Sol. Energy Mater. Sol. Cells. 67, 397-403.

Fraunhofer Institute for Solar Energy Systems, 2016. Photovoltaics Report.

Frisson, L., Lieten, K., Bruton, T., Declercq, K., Szlufcik, J., de Moor, H., Goris, M., Benali, A., Aceves, A., 2000. Recent improvements in industrial PV module recycling. In: Proceedings of the 16th European Photovoltaic Solar Energy Conference and Exhibition (EUPVSEC), Glasgow, pp. 2160-2163.

Fthenakis, V.M., 2000, a. End-of-life management and recycling of PV modules. Energy Policy. 28, 10511058

Fthenakis, V.M., Moskowitz, P.D., 2000, b. Photovoltaics: Environmental, health and safety issues and perspectives. Prog. Photovoltaics Res. Appl. 8, 27-38.

Granata, G., Pagnanelli, F., Moscardini, E., Havlik, T., Toro, L., 2014. Recycling of photovoltaic panels by physical operations. Sol. Energy Mater. Sol. Cells. 123, 239-248. 
Huang, W.H., Tao, M., 2015. A simple green process to recycle Si from crystalline-Si solar cells. In: Proceedings of the 42nd IEEE Photovoltaic Specialist Conference (PVSC), New Orleans, pp. 1-5.

Huang, W.H., Shin, W.J., Wang, L., Tao, M., 2016. Recovery of valuable and toxic metals from crystallineSi modules. In: Conference Record of the 43rd IEEE Photovoltaic Specialist Conference (PVSC), Portland.

International Renewable Energy Agency, 2016. End-of-Life Management: Solar Photovoltaic Panels..

Kang, S., Yoo, S., Lee, J., Boo, B., Ryu, H., 2012. Experimental investigations for recycling of silicon and glass from waste photovoltaic modules. Renew. Energy. 47, 152-159.

Kim, Y., Lee, J., 2012. Dissolution of ethylene vinyl acetate in crystalline silicon PV modules using ultrasonic irradiation and organic solvent. Sol. Energy Mater. Sol. Cells. 98, 317-322.

Klugmann-Radziemska, E., Ostrowski, P., 2010, a. Chemical treatment of crystalline silicon solar cells as a method of recovering pure silicon from photovoltaic modules. Renew. Energy. 35, 1751-1759.

Klugmann-Radziemska, E., Ostrowski, P., Drabczyk, K., Panek, P., Szkodo, M., 2010, b. Experimental validation of crystalline silicon solar cells recycling by thermal and chemical methods. Sol. Energy Mater. Sol. Cells. 94, 2275-2282.

Mecucci, A., Scott, K., 2002. Leaching and electrochemical recovery of copper, lead and tin from scrap printed circuit boards. J. Chem. Technol. Biotechnol. 77, 449-457.

Muller, A., Wambach, K., Alsema, E., 2005. Life cycle analysis of solar module recycling process. In: MRS Proceedings. 895, pp. G03/7.1-7.6.

Muller, A., Rover, I., Wambach, K., von Ramin-Marro, D.W., 2007. Recovery of high value material of different photovoltaic technologies. In: Proceedings of the 22nd European Photovoltaic Solar Energy Conference and Exhibition (EUPVSEC), Milan, pp. 2613-2616.

Park, J., Park, N., 2014. Wet etching processes for recycling crystalline silicon solar cells from end-of-life photovoltaic modules. RSC Adv. 4, 34823-34829.

PV CYCLE, http://www.pvcycle.org/.

Rover, I., Wambach, K., Weinreich, W., Roewer, G., Bohmhammel, K., 2005. Process controlling of the etching system $\mathrm{HF} / \mathrm{HNO}_{3} / \mathrm{H}_{2} \mathrm{O}$. In: Proceedings of the 20th European Photovoltaic Solar Energy Conference and Exhibition (EUPVSEC), Barcelona.

Tammaroa, M., Salluzzoa, A., Rimauroa, J., Schiavob, S., Manzo, S., 2016. Experimental investigation to evaluate the potential environmentalhazards of photovoltaic panels. J. Hazard. Mater. 306, 395-405.

Tao, C.S., Jiang, J., Tao, M., 2011. Natural resource limitations to terawatt-scale solar cells. Sol. Energy Mater. Sol. Cells. 95, 3176-3180.

Tao, M., 2014. Terawatt Solar Photovoltaics: Roadblocks and Opportunities. Springer., London.

U.S. Department of Agriculture, 2011. Supplemental Technical Report for Sodium Nitrate (Crops).

U.S. Geological Survey, 2015. Mineral Commodity Summaries. 
van den Broeck, K., van Hoornick, N., van Hoeymissen, J., de Boer, R., Giesen, A., Wilms, D., 2003. Sustainable treatment of HF wastewaters from semiconductor industry with a fluidized bed reactor. IEEE Trans. Semicond. Manuf. 16, 423-428.

Wang, T.Y., Hsiao, J.C., Du, C.H., 2012. Recycling of materials from silicon base solar cell module. In: Proceedings of the 38th IEEE Photovoltaic Specialist Conference (PVSC), Austin, pp. 2355-2358.

Yoo, K., Lee, J.C., Lee, K.S., Kim, B.S., Kim, M.S., Kim, S.K., Pandey, B.D., 2012. Recovery of Sn, Ag and $\mathrm{Cu}$ from waste $\mathrm{Pb}$-free solder using nitric acid leaching. Mater. Trans. 53, 2175-2180.

Zeng, D.W., Born, M., Wambach, K., 2004. Pyrolysis of EVA and its application in recycling of photovoltaic modules. J. Environ. Sci. 16, 889-893. 
A multi-step process is proposed to break down $\mathrm{Si}$ modules and recover almost all the materials. New technologies are demonstrated for the recycling process including sequential electrowinning to recover multiple metals one by one from $\mathrm{Si}$ modules, $\mathrm{Ag}, \mathrm{Pb}, \mathrm{Sn}$ and $\mathrm{Cu}$, and sheet resistance monitoring to maximize the amount of solar-grade $\mathrm{Si}$ recovered from $\mathrm{Si}$ modules. The recovered Si and metals are new feedstocks to the solar industry. They generate $\$ 11-12 /$ module in revenue to cover the cost of recycling.
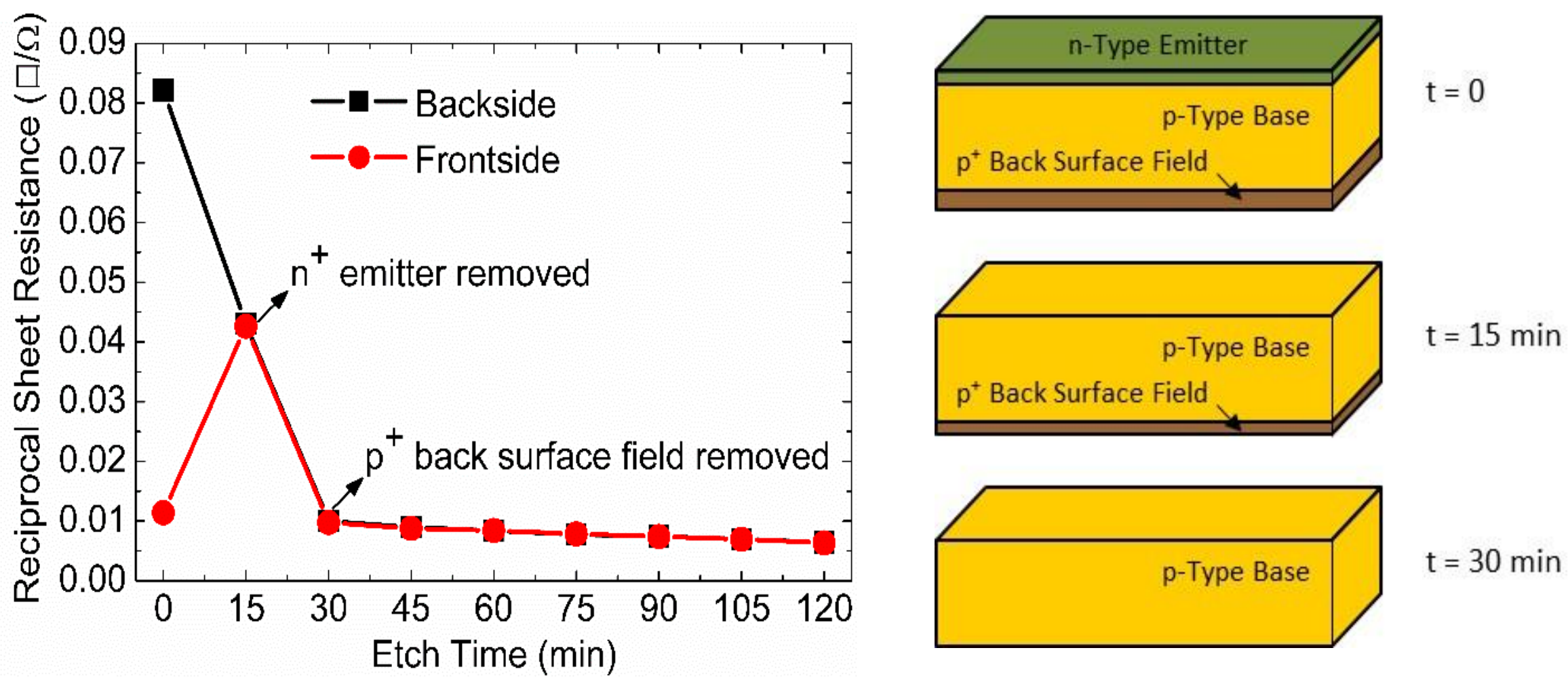